Fishing Resources / Aquaculture Received on: 30/06/2020

Accepted on: 09/12/2020

\title{
Mango pulp meal in diets for Nile tilapia (Oreochromis niloticus): Digestibility, Growth performance, Biochemical analysis, Digestive enzyme activity, hematological variables
}

Farinha de polpa de manga em dietas para tilápia do Nilo (Oreochromis niloticus): Digestibilidade, Crescimento; Análise bioquímica; Atividade de enzimas digestivas; variáveis hematológicas

SOUZA, Seldon Almeida de ${ }^{1}$

https://orcid.org/0000-0001-7999-0809

SOUZA, Anderson Miranda de Souza ${ }^{2}$ https://orcid.org/0000-0002-4736-0340
SOUZA, Renilde Cordeiro de Souza ${ }^{1}$

https://orcid.org/0000-0002-2655-1199

MELO, José Fernando Bibiano ${ }^{1}$ https://orcid.org/0000-0003-2068-4641

VIDAL, Luiz Vitor Oliveira ${ }^{3}$ https://orcid.org/0000-0001-9539-3510

${ }^{1}$ Campus Ciências Agrárias, Universidade Federal do Vale do São Francisco, Rodovia BR 407, km 12, Lote 543, Projeto de Irrigação Nilo Coelho, CEP: 56300-000, Petrolina-PE, Brasil.

${ }^{2}$ Centro Multidisciplinar da Barra, Universidade Federal do Oeste da Bahia, Rua Teixeira de Freitas, S/n - Assunção, Barra - BA, 47100-000, Barra, Brasil

${ }^{3}$ Departamento de Zootecnia, Escola de Medicina Veterinária e Zootecnia, Universidade Federal da Bahia, Av. Adhemar de Barros, 500, Ondina, CEP: 40170-110, Salvador-BA, Brasil.

\begin{abstract}
The objective of this study was to evaluate the potential of mango pulp meal (MPM) as an ingredient for extruded diets for Nile tilapia juveniles. In the first trial, the digestibility of energy, dry matter, crude protein, and amino acids was determined, using 80 juveniles (average weight $25.00 \pm 0.50 \mathrm{~g}$ ), fed with a reference diet and a test diet containing the proportion of $70 \%$ of the reference diet and $30 \%$ of the MPM. Chromium oxide (Cr2O6) was used as an digestibility indicator and feces were collected using the Adapted Guelph System. The second assay assessed the growth performance; biochemical analysis; digestive enzyme activity; hematological variables for 300 juveniles fish (average weight $26.66 \pm 0.17 \mathrm{~g}$ ), fed for 45 days with balanced diets containing 0 (control), 40, 80, 120, and $160 \mathrm{~g}$ of MPM per $\mathrm{kg}^{-1}$. The dry matter, crude protein, and crude energy apparent digestibility coefficients of MPM were 39.26, 50.18 , and $44.5 \%$, respectively. The growth performance of the animals was negatively impacted by the MPM, however the hematological parameters and plasma concentrations of albumin, total proteins and cholesterol were not altered. However, the increase on hepatic glycogen reserves, glycemia, and alanine aminotransferase plasmatic enzyme activity demonstrated that MPM diet inclusion promoted oxidative metabolism conditions that could cause hepatocellular damage and affect fish health, if fed for long periods or at higher levels of MPM than analyzed in this study.
\end{abstract}

Keywords: energetic ingredient, carbohydrates, agroindustry residues, fish farming. 


\section{RESUMO}

O objetivo deste estudo foi avaliar o potencial do farelo de polpa de manga (FPM) como ingrediente para dietas extrusadas para juvenis de tilápia do Nilo. No primeiro ensaio, a digestibilidade da energia, matéria seca, proteína bruta e aminoácidos foi determinada, utilizando 80 juvenis (peso médio 25,00 $\pm 0,50 \mathrm{~g}$ ) alimentados com uma dieta referencia e uma dieta teste contendo a proporção de $70 \%$ da dieta referencia e $30 \%$ do FPM. Foi utilizado o óxido de cromo $\left(\mathrm{Cr}_{2} \mathrm{O}_{6}\right)$ como indicador de digestibilidade e as fezes foram coletadas por meio do Sistema de Guelph Adaptado. O segundo ensaio avaliou desempenho, analyses bioquimicas, atividades de enzimas digestivas e variáveis hematológicas de 300 jovens (peso médio 26,66 \pm $0,17 \mathrm{~g}$ ), alimentados com dietas balanceadas contendo 0 (controle), 40, 80, 120 e $160 \mathrm{~g}$ de FPM por kg de dieta por 45 dias. Os coeficientes de digestibilidade aparente da matéria seca, proteína bruta e energia bruta do MPM foram 39,26, 50,18 e 44,5\%, respectivamente. O desempenho dos animais foi impactado negativamente pela FPM, porém os parametros hematologicos e concentrações plasmáticas de albumina, proteínas totais e cholesterol não foram alterados. $\mathrm{O}$ aumento ds reservas hepáticas de glicogênio, glicemia e atividade enzimática plasmática da alanina aminotransferase demonstraram que a inclusão da dieta MPM promoveu condições de metabolismo oxidativo que poderiam causar danos hepatocelulares e afetar a saúde dos peixes, se alimentados por longos períodos ou em níveis mais altos de MPM do que o analisado neste estudo.

Palavras-chave: ingrediente energético, carboidratos, resíduos da agroindústria, piscicultura.

\section{INTRODUCTION}

In aquaculture, the possibility of totally or partially replacing traditional ingredients used in diet formulations with alternatives is of great interest. In the evaluation process, the nutritional value of the ingredients must be considered, in addition to the possibility of replacing totally or partially the ingredients of traditional crops (GLENCROSS et al., 2007). Alternative ingredients include non-traditional crop products (DE SoUZA et al., 2018) or even residues from the agribusiness (FELIX E SILVA et al., 2020), enabling the reduction of the impact of activities with large disposal of by-products (SILVA et al., 2018). The fruit agribusiness is an important economic activity in tropical and subtropical countries, and generates large amounts of waste during production and after harvest (MARTINS AND FARIAS, 1994; DURIGAN et al., 2005). Fruits with mechanical or aesthetic damage are often discarded during these phases, and can become a waste product (DE CAMPOS AND DE LIMA, 2014). On the other hand, fruits, as well as their parts are rich in carbohydrates such as reductors sugar, and pectical substances, which can make them potential substitutes for traditional energy ingredients (KROGDAHL et al., 2005).

In this scenario, mango fruit (Mangifera indica L.) has the characteristics to be a possible substitute for traditional energetic ingredients (LAZZARI et al., 2015), with studies carried out with fish and other nonruminant organisms (VIEIRA et al., 2008; MELO et al., 2012; BEZERRA et al., 2014). In addition to the growth parameters of fish, the use of alternative ingredients can cause changes in animal's health and metabolism. When considering alternative energetic ingredients, due to the change in the carbohydrate matrix, we can observe differences in carbohydrate metabolism, consequently, energy and protein metabolism (DE SOUZA et al., 2018; FELIX E SILVA et al., 2020).

In this context, the purpose of the present study was to determine the apparent digestibility (energy, dry matter, crude protein, carbohydrates and amino acids), growth performance; biochemical analysis; 
digestive enzyme activity; hematological variables of juvenile Nile tilapia (Oreochromis niloticus), by feeding them diets containing variable levels of mango pulp meal. Thus, to determine the potential use of this residue from the fruit agroindustry in the feeding of Nile tilapia.

\section{MATERIAL AND METHODS}

This experiment was performed at the Aquaculture Laboratory of Universidade Federal do Vale do São Francisco UNIVASF -, Campus Ciências Agrárias, in Petrolina city Pernambuco state. This study was approved by the ethics committee of Universidade Federal da Bahia, process number 54/2015 of CEUA/EMVZ/UFBA.

The experiment had two phases. The purpose of the first phase was to evaluate the chemical composition and amino acids profile of mango pulp meal (MPM), and to determine its apparent digestibility coefficients (ADCs) of dry matter (ADCDM), crude protein (ADCCP) and gross energy (ADCGE), and availability of essential amino acids (AEAAs) and non- essential amino acids (ANEAAs) for juvenile Nile tilapia. The purpose of the second phase was to determine the growth performance of juvenile tilapia that received diets containing levels of MPM, and the effects of MPM levels on metabolism, intestinal enzymatic activity, and metabolic plasma concentrations.

\section{Manufacture and chemical composition of $M P M$}

Multiple cultivars mangoes fruits, such as Tommy Atkins, unsuitable for human consumption, were collected at the "Mercado do Produtor" in Juazeiro/BA. The fruits were processed in a Max Machine pulper, model MDP-150, to separate the epicarp, mesocarp (pulp) and endocarp. Thus, the pulp, the part with the highest concentration of soluble carbohydrates, was dried in a forced ventilation oven $\left(55^{\circ} \mathrm{C}\right)$ for 48 hours. The dry pulp was ground in a knife mill, using a $1 \mathrm{~mm}$ sieve. At the end of the processing, mango pulp meal (MPM) was obtained (Table 1). 
Table 1. Analyzed composition of the mango pulp meal

\begin{tabular}{cc}
\hline Nutrient & $\mathrm{g} \mathrm{kg}^{-1}$ \\
\hline Dry matter $\left(\mathrm{g} \mathrm{kg}^{-1}\right)$ & 910.00 \\
Ash $\left(\mathrm{g} \mathrm{kg}^{-1}\right)^{1}$ & 21.5 \\
Crude protein $\left(\mathrm{g} \mathrm{kg}^{-1}\right)$ & 45.00 \\
Gross energy $\left(\mathrm{kcal} \mathrm{kg}^{-1}\right)$ & 4025.27 \\
Crude fiber $\left(\mathrm{g} \mathrm{kg}^{-1}\right)$ & 99.40 \\
Total phenols $\left(\mathrm{gAT} \mathrm{kg}^{-1}\right)$ & 0.62 \\
Essential amino acids $\left(\mathrm{g} \mathrm{kg}^{-1}\right)$ & \\
Arginine & 5.49 \\
Phenylalanine & 1.87 \\
Histidine & 0.88 \\
Isoleucine & 2.09 \\
Leucine & 3.74 \\
Lysine & 1.54 \\
Methionine & 0.55 \\
Methionine + Cysteine & 1.76 \\
Threonine & 4.18 \\
Tryptophan & 0.99 \\
Valine & 2.20 \\
Aspartic acid & \\
Glutamic acid & 3.96 \\
Alanine & 4.73 \\
Cysteine & 4.18 \\
Glycine & 1.21 \\
Proline & 2.31 \\
Serine & 2.53 \\
Tyrosine & 2.31 \\
& 1.65 \\
\hline Non-essential amino acids $\left(g \mathrm{~kg}^{-1}\right)$ & \\
Con & \\
\hline
\end{tabular}

\section{Digestibility trial}

Experimental facilities, animals, and sample collections

Eighty juvenile reversed sex Nile tilapias $(25.00 \pm 0.50 \mathrm{~g})$ were allocated randomly to eight conical bottom tanks (200 L). Tanks were connected with a recirculation water system consisting of a shared water supply and individual drainage for each tank. The system included, for each tank, a central activated carbon filter with a perlon acrylic cover, and a biological filter with a reservoir of gravel substrate for bacteria that break down ammonia. Aeration was supplied by a central blower connected to plastic hoses and porous stones supplying each individual tank of experimental fish.

Fish were allowed to adapt to tank conditions and experimental diets for four days before fecal sample collections began. The fecal samples were collected into coolers with ice. There were two types of diet: a reference diet (basal), and a test diet composed of $70 \%$ of the reference diet (Table 2) and 30\% MPM. 
Table 2. Chemical composition and amino acid profile reference and test diets

\begin{tabular}{|c|c|c|}
\hline Ingredients & \multicolumn{2}{|c|}{$\mathrm{g} \mathrm{kg}^{-1}$} \\
\hline Mango pulp meal & 0.00 & 300.00 \\
\hline Poultry by-product meal & 305.00 & 213.50 \\
\hline Wheat middlings & 263.8 & 184.66 \\
\hline Corn & 181.00 & 126.70 \\
\hline Corn gluten meal & 130.00 & 91.00 \\
\hline Soybean meal & 106.00 & 74.20 \\
\hline Mineral and vitamin mixture ${ }^{a}$ & 5.00 & 3.50 \\
\hline Dicalcium phosphate & 5.00 & 3.50 \\
\hline Vitamin $C^{b}$ & 2.00 & 1.40 \\
\hline Antifungal $^{\mathrm{c}}$ & 1.00 & 0.70 \\
\hline Chromium Oxide III & 1.00 & 0.70 \\
\hline B.H.T ${ }^{d}$ & 2.00 & 1.40 \\
\hline \multicolumn{3}{|l|}{ Analyzed chemical composition } \\
\hline Dry matter & 964.00 & 948.00 \\
\hline Ash & 63.16 & 50.60 \\
\hline Crude protein & 418.05 & 308.44 \\
\hline Gross energy $\left(\mathrm{kcal} \mathrm{kg}^{-1}\right)$ & 4798.76 & 4863.92 \\
\hline Crude fiber & 56.32 & 69.18 \\
\hline \multicolumn{3}{|l|}{ Essential amino acids } \\
\hline Arginine & 22.90 & 16.98 \\
\hline Phenylalanine & 21.20 & 15.61 \\
\hline Histidine & 7.00 & 5.06 \\
\hline Isoleucine & 18.00 & 13.50 \\
\hline Leucine & 42.50 & 31.22 \\
\hline Lysine & 18.90 & 13.40 \\
\hline Methionine & 7.20 & 4.85 \\
\hline Methionine + Cysteine & 13.10 & 9.81 \\
\hline Threonine & 16.30 & 11.60 \\
\hline Tryptophan & 2.80 & 2.11 \\
\hline Valine & 20.70 & 16.24 \\
\hline \multicolumn{3}{|l|}{ Non-essential amino acids } \\
\hline Aspartic acid & 33.70 & 25.42 \\
\hline Glutamic acid & 7.15 & 52.32 \\
\hline Alanine & 33.60 & 25.11 \\
\hline Cysteine & 5.90 & 4.96 \\
\hline Glycine & 27.30 & 20.46 \\
\hline Proline & 31.80 & 23.73 \\
\hline Serine & 22.70 & 16.03 \\
\hline Tyrosine & 13.50 & 11.71 \\
\hline
\end{tabular}

${ }^{\mathrm{a}}$ Mineral and vitamin mixture: Cobalt (minimum) $80 \mathrm{mg} \mathrm{kg}^{-1}$; Copper (minimum) $3.500 \mathrm{mg} \mathrm{kg}^{-1}$; Iron (minimum) $20 \mathrm{~g} \mathrm{~kg}^{-1}$; Iodine (minimum) $160 \mathrm{mg} \mathrm{kg}^{-1}$; Manganese (minimum) $10.000 \mathrm{mg} \mathrm{kg}^{-1}$; Selenium (minimum) $100 \mathrm{mg} \mathrm{kg}^{-1}$; (minimum) $24 \mathrm{mg} \mathrm{kg}^{-1}$; Folic acid (minimum) $1200 \mathrm{mg} \mathrm{kg}^{-1}$; Nicotinic acid (minimum) $20 \mathrm{~g} \mathrm{~kg}^{-1}$; Uric acid (minimum) $10.000 \mathrm{mg} \mathrm{kg}{ }^{-1}$; Biotin (minimum) $200 \mathrm{mg} \mathrm{kg}$; Choline (minimum) $100 \mathrm{~g} \mathrm{~kg}^{-1}$; Inositol (minimum) $25 \mathrm{~g} \mathrm{~kg}^{-1}$; Vitamin A (minimum) 2.400.000 UI kg-1; Vitamin B1 (minimum) $4.000 \mathrm{mg} \mathrm{kg}^{-1}$; Vitamin B2 (minimum) $4.000 \mathrm{mg} \mathrm{kg}^{-1}$; Vitamin B12 (minimum) $8.000 \mathrm{mg} \mathrm{kg}^{-1}$; Vitamin C (minimum) $60 \mathrm{~g} \mathrm{~kg}^{-1}$; Vitamin B2 (minimum) $4.000 \mathrm{mg} \mathrm{kg}^{-1}$; Vitamin B6 (minimum) $3.500 \mathrm{mg} \mathrm{kg}^{-1}$; Vitamin D3 (minimum) 600.000 
UI kg-1; Vitamin E (minimum) $30.000 \mathrm{UI} \mathrm{kg}^{-1}$; Vitamin $\mathrm{K} 3$ (minimum) $3.000 \mathrm{mg} \mathrm{kg}^{-1}$. ${ }^{\text {b }}$ Vitamin $\mathrm{C}$ resistant to high pressure and high temperatures, insoluble in water. ${ }^{\mathrm{c}}$ Calcium propionate. ${ }^{\mathrm{d}}$ Antioxidant $=$ di-terc-butyl methyl phenol or buzzarded hydroxitolen. ${ }^{\mathrm{e}}$ According to Furuya et al. (2010).

TD composed of $70 \%$ of RD and $30 \%$ of MPM; Crude protein: Nitrogen x 6.25.

The experimental fish were fed five times a day between 07:00 and 17:00, until they were visibly satiated. One hour after the last feeding of the day, water circulation was closed, each tank was cleaned, and the water was partially changed, while the central blower remained active. Fecal collection tubes, which were individually attached to the bottom each tank, were collected, and stored in coolers with ice. At $0,600 \mathrm{hr}$ the morning after collections, fecal collection tubes were centrifuged. Material in the sediment was saved and other material was discarded. The material was then fine-strained and deposited in plastic bottles labeled for each tank. Feces were pooled between collections into the same bottle for each replicate. These samples were kept frozen at $-21^{\circ} \mathrm{C}$ until the end of the collection period.

Chemical analysis of ingredients, diets, and faeces

After each experimental period, feces were dehydrated in a forced ventilation oven at $55^{\circ} \mathrm{C}$ for $48 \mathrm{~h}$; the same procedure was applied to the ingredients and the experimental diets, but only for $24 \mathrm{~h}$. All sample materials were then ground in a ball mill.

Dry matter and ash content were measured according to standard methods (AOAC, 2005). Moisture content was determined by drying the samples to a constant weight at $105^{\circ} \mathrm{C}$ in a furnace (TE-391-1, Tecnal). Nitrogen content was determined using the Micro-Kjeldahl (Tecnal) method, and the crude protein content was estimated by multiplying the nitrogen content by 6.25 (FURUKAWA AND TSUKAHARA, 1966). Lipid content was determined by ether extraction in a multi-unit Soxhlet apparatus (TE-188/6, Tecnal) for $16 \mathrm{~h}$. Ash content was measured by combustion. Samples were dried in a muffle furnace (TE-1100$1 \mathrm{P}$, Tecnal) at $550^{\circ} \mathrm{C}$ for $6 \mathrm{~h}$, and crude energy content was assessed using an adiabatic bomb calorimeter (Parr 1266, Parr Instruments Co., Moline, Illinois, USA).

Amino acids were measured commercially by CBO Analysis Laboratory Ltda., Valinhos, São Paulo, Brazil by hydrolyzing a $0.3-\mathrm{mg}$ sample in $1 \mathrm{~mL}$ of $6 \mathrm{~N} \mathrm{HCl}$ for 22 h. The obtained sample was diluted in 0.02 $\mathrm{N} \mathrm{HCl}$ and injected into an automatic AA analyzer (Hitachi L-888, Tokyo, Japan). Hydrolysis was performed to recover the amino acids using 4-N methanesulfonic acid for tryptophan analysis, and sulfuric acid for amino acid analysis. Chromium (III) oxide $\left(\mathrm{Cr}_{2} \mathrm{O}_{3}\right)$ levels were measured using inductively coupled plasma atomic emission spectrophotometry (ICP-AES, Vista-MPX, Varian, Palo Alto, California, USA) after digestion with perchloric acid, following a technique modified from Bezerra Neto and Barreto (2011).

Concentrations of total phenols and tannins in MPM and in experimental diets were determined according to the (AOAC, 2005) acetone extraction method (70\%), and colorimetric titration with the FolinCiocalteau reagent, sodium carbonate (20\%), and insolubilized polyvinylpyrrolidone. Standardized readings were derived from a tannic acid curve $\left(0.1 \mathrm{mg} \mathrm{mL}^{-1}\right)$ and the results were expressed as mg equivalents of tannic acid per kg of dry matter (DM).

Calculation of apparent digestibility coefficients and availability of amino acids

Nutrient and energy ADCs, in addition to AEAAs and ANEAAs, were calculated based on chromium levels in food and feces according equations 1 and 2, following (NRC, 2011): 
Equation 1: $A D C_{\text {diet }}(\%)=(100-$ [ chromium in feed/ chromium in feces] $\times$ [ energy or nutrient in feces / energy or nutrient in feed] $\times 100$ ) where $\operatorname{ADC}(\mathrm{n})=$ apparent digestibility coefficients,

Equation 2:

$A D C$ of test ingredient $(\%)=$ $A D C_{\text {test diet }}+\left[\left(A D C_{\text {test diet }}-\right.\right.$ $\left.A D C_{\text {reference diet }}\right) \times(0.7 \times D$ reference $/$ $0.3 \times$ Dingredient $)]$,

where $D_{\text {reference }}$ and $D_{\text {ingredient }}$ are the percentages of the nutrients or kcal g-1 gross energy in the reference diet and test ingredients, respectively.

\section{MPM inclusion trial}

Fish, experimental conditions, facilities, and diets manufacture
A 45 day trial was conducted to evaluate performance of 300 male, sexually reversed, juvenile Nile tilapia (average weight $26.66 \pm 0.17 \mathrm{~g}$ ) given diets with different concentrations of MPM. The fish were obtained from AAT International Ltda. (Paulo Afonso-BA) and randomly distributed into 20 plastic circular tanks (500 L each). Each tank had a recirculation system with a physical central active carbon filter and a perlon-type acrylic cover. Aeration was supplied to tanks with a central blower connected to plastic hoses leading to porous stones.

Five diet types were tested, containing 0 , $40,80,120$, or $160 \mathrm{~g}$ of MPM per kg of diet (Table 3). Each diet type was randomly assigned to each of four tanks. Fish were fed four times a day until visible satiation, at $08,00 \mathrm{hr}, 11,00 \mathrm{hr}, 14,00 \mathrm{hr}$, and $17,00 \mathrm{hr}$. 
Table 3. Formulation and proximal composition of trial diets of mango pulp meal for juvenile Nile tilapia.

\begin{tabular}{|c|c|c|c|c|c|}
\hline \multirow{2}{*}{ Ingredients } & \multicolumn{5}{|c|}{ Mango inclusion $\left(\mathrm{g} \mathrm{kg}^{-1}\right)$} \\
\hline & 0 (control) & 40 & 80 & 120 & 160 \\
\hline Corn & 280.00 & 280.00 & 280.00 & 280.00 & 280.00 \\
\hline Wheat middlings & 255.00 & 217.00 & 179.60 & 141.90 & 104.20 \\
\hline Poultry by-product meal & 200.00 & 200.00 & 200.00 & 200.00 & 200.00 \\
\hline Corn gluten meal & 71.00 & 71.00 & 71.00 & 71.00 & 71.00 \\
\hline Soybean meal & 160.00 & 160.00 & 160.00 & 160.00 & 160.00 \\
\hline Cellulose & 18.00 & 13.80 & 9.00 & 4.50 & 0.00 \\
\hline DL-Methionine & 0.80 & 3.00 & 5.20 & 7.40 & 9.60 \\
\hline Mineral and vitamin mixture ${ }^{a}$ & 5.00 & 5.00 & 5.00 & 5.00 & 5.00 \\
\hline Dicalcium Phosphate & 5.00 & 5.00 & 5.00 & 5.00 & 5.00 \\
\hline Choline Chloride & 2.00 & 2.00 & 2.00 & 2.00 & 2.00 \\
\hline Vitamin $C^{b}$ & 2.00 & 2.00 & 2.00 & 2.00 & 2.00 \\
\hline Calcium Propionate & 1.00 & 1.00 & 1.00 & 1.00 & 1.00 \\
\hline B.H.T ${ }^{\mathrm{c}}$ & 0.20 & 0.20 & 0.20 & 0.20 & 0.20 \\
\hline Mango pulp meal ${ }^{\mathrm{d}}$ & 0.00 & 40.00 & 80.00 & 120.00 & 160.00 \\
\hline Nutrients & \multicolumn{5}{|c|}{ Calculated proximal composition ${ }^{e}$} \\
\hline Digestible protein $\left(\mathrm{g} \mathrm{kg}^{-1}\right)$ & 261.40 & 261.00 & 260.70 & 260.30 & 260.00 \\
\hline $\operatorname{Ash}\left(\mathrm{g} \mathrm{kg}^{-1}\right)$ & 60.60 & 58.60 & 56.70 & 54.70 & 52.70 \\
\hline Digestible energy $\left(\mathrm{kcal} \mathrm{kg}^{-1}\right)$ & 3077.17 & 3061.88 & 3046.59 & 3031.30 & 3016.01 \\
\hline Crude fiber $\left(\mathrm{g} \mathrm{kg}^{-1}\right)$ & 59.30 & 57.50 & 55.70 & 53.80 & 52.00 \\
\hline Ether extract $\left(\mathrm{g} \mathrm{kg}^{-1}\right)$ & 46.30 & 46.90 & 47.50 & 48.10 & 48.70 \\
\hline \multicolumn{6}{|l|}{ Digestible amino acids $\left(\mathrm{g} \mathrm{kg}^{-1}\right)$} \\
\hline Arginine & 17.10 & 16.90 & 16.70 & 16.40 & 16.20 \\
\hline Phenylalanine & 12.80 & 12.70 & 12.60 & 12.40 & 12.30 \\
\hline Histidine & 6.40 & 6.30 & 6.20 & 6.10 & 6.00 \\
\hline Isoleucine & 10.10 & 10.20 & 10.30 & 10.50 & 10.60 \\
\hline Leucine & 23.90 & 23.80 & 23.60 & 23.50 & 23.30 \\
\hline Lysine & 16.70 & 16.60 & 16.50 & 16.30 & 16.20 \\
\hline Methionine + Cysteine & 8.00 & 7.90 & 7.90 & 7.80 & 7.70 \\
\hline Methionine & 5.60 & 7.70 & 9.80 & 11.90 & 14.10 \\
\hline Threonine & 8.60 & 8.60 & 8.50 & 8.50 & 8.40 \\
\hline Tryptophan & 3.00 & 3.00 & 3.00 & 2.90 & 2.90 \\
\hline Valine & 12.00 & 11.90 & 11.80 & 1.20 & 1.20 \\
\hline
\end{tabular}

aMineral and vitamin mixture: Cobalt (minimum) $80.00 \mathrm{mg} \mathrm{kg}{ }^{-1}$; Copper (minimum) 3,500.00 mg kg-1 Iron (minimum) $20.00 \mathrm{~g} \mathrm{~kg}^{-1}$; Iodine (minimum) $160.00 \mathrm{mg} \mathrm{kg}^{-1}$; Manganese (minimum) 10,000.00 mg kg-1; Selenium (minimum) $100.00 \mathrm{mg} \mathrm{kg}^{-1}$; (minimum) $24.00 \mathrm{mg} \mathrm{kg}^{-1}$; Folic Acid (minimum) $1200.00 \mathrm{mg} \mathrm{kg}^{-1}$; Nicotinic Acid (minimum) $20.00 \mathrm{~g} \mathrm{~kg}^{-1}$; Uric Acid (minimum) 10,000.00 mg kg-1; Biotin (minimum) $200.00 \mathrm{mg} \mathrm{kg}^{-1}$; Choline (minimum) $100.00 \mathrm{~g} \mathrm{~kg}^{-1}$; Inositol (minimum) $25.00 \mathrm{~g} \mathrm{~kg}^{-1}$; Vitamin A (minimum) 2,400,000.00 UI kg ${ }^{-1}$; Vitamin B1 (minimum) 4,000,00 mg kg-1; Vitamin B2 (minimum) 4,000.00 mg kg-1; Vitamin B12 (minimum) 8,000.00 
mg kg${ }^{-1}$; Vitamin C (minimum) $60.00 \mathrm{~g} \mathrm{~kg}^{-1}$; Vitamin B2 (minimum) 4,000.00 $\mathrm{mg} \mathrm{kg}^{-1}$; Vitamin B6 (minimum) $3,500.00 \mathrm{mg} \mathrm{kg}^{-1}$; Vitamin D3 (minimum) 600,000.00 UI kg${ }^{-1}$; Vitamin E (minimum) 30,000.00 UI kg- ${ }^{-1}$; Vitamin $\mathrm{K} 3$ (minimum) 3,000.00 $\mathrm{mg} \mathrm{kg}^{-1}$. ${ }^{\mathrm{b}}$ Vitamin $\mathrm{C}$ resistant to high pressures and temperatures. ${ }^{\mathrm{c}}$ Antioxidants $=$ diterc-butyl methyl phenol or buzzarded hydroxitolen.. ${ }^{\mathrm{d}}$ The MPM digestible energy and nutrients were determined in the first phase of the study. ${ }^{\mathrm{e}}$ According to Furuya et al. (2010)

Water quality parameters (temperature, $\mathrm{pH}$, and dissolved oxygen) were measured daily in the morning and in the afternoon throughout the entire experimental period using a multiparametric digital Alfakit $^{\circledR}$ (AT1100) rig.

\section{Growth performance}

After the 45 day feeding experiment period, all fish were starved for a 24 hours, and then anesthetized in order to collect blood and biometric data. After this, fish were euthanized and their livers were dissected for further analysis. Data collected on fish included: final weight (FW); final biomass (FB); weight gain ( $W G=$ Final weight - Initial weight);

biomass gain $(B G=$
Final biomass - Initial biomass $)$
hepatic-somatic index (HSI $=100 \times$
$[($ liver weight)/
(fish weight)]); thermal growth coefficient $\quad(T G C=[(\sqrt[3]{\text { Final weight }}-$ $\sqrt[3]{\text { Initial weight }) / ~}$ (average temperature $\times$ days) $] \times$ $1000)$; feed intake (FI); Feed conversion ratio

feed intake/weight gain).

\section{Biochemical analysis}

Plasmatic evaluations of metabolic intermediates were made using LABTEST ${ }^{\circledR}$ industrial kits for colorimetric determination of glucose (GLUCOSE LIQUIFORM $^{\circledR}$ ), total proteins (TOTAL PROTEINS ${ }^{\circledR}$, BIURETO method) and total cholesterol

(CHOLESTEROL LIQUIFORM $\left.^{\circledR}\right)$. Both analyses were conducted with a biochemical semiautomatic veterinary device (Doles ${ }^{\circledR}$, model D-250).
Free plasmatic amino acid dosage was measured using the Ninhidrine $0,10 \%$ method in propanol, with a standard curve based on a glycine solution of 1.00 millimolar $(\mathrm{mM})$, and read via spectrophotometer wavelength of 570 nanometers $(\mathrm{nm})$.

The plasmatic activity of the enzyme alanine aminotransferase (ALT) was measured with an ALT/GPT Liquiform ${ }^{\circledR}$ kit and read with a spectrophotometer with a wavelength of $340 \mathrm{~nm}$ at one and three minutes into the reaction. The activity was considered the difference between the two measurements.

Glycogen content of liver tissue was determined following Bidinotto et al. (1997). Liver fragments were weighed and then put in potassium hydroxide $(\mathrm{KOH})$ with 6.00 normal $(\mathrm{N})$. Glycogen contents were extracted with ethanol, centrifuged, and reacted with potassium sulphate $\left(\mathrm{K}_{2} \mathrm{SO}_{4}\right)$, water, and phenol. Reaction readings were taken using a spectrophotometer with a wavelength of $480 \mathrm{~nm}$, and compared to the standard curve for glucose, with values in expressed in micromoles per milligram of hepatic tissue $\left(\mu \mathrm{mol} \mathrm{mg} \mathrm{m}^{-1}\right.$.

\section{Digestive enzyme activity}

For intestinal amylase evaluation, six fish were randomly selected from each treatment and a $3.00 \mathrm{~cm}$ portion of intestinal segment was collected from each (before final gastric expansion). Each adipose tissue segment and the rest of the mesentery were taken. Each intestinal fragment was weighed, put in a sample tube with a 2.00 $\mathrm{mL}$ buffer solution (tris-phosphate-acid phosphoric-glycerin, $\mathrm{pH}=7.00$ ), and macerated using a mechanical tissue refrigerated homogenizer. After tissue 
maceration, tubes were centrifuged at $12,000 \mathrm{rpm}$ for three minutes in a refrigerated centrifuge. Then, intestinal amylase enzyme activity was measured using an Amylases Bioclin ${ }^{\circledR}$ commercial test kit and a semiautomatic evaluator (Trademark Doles ${ }^{\circledR}$, model D-250). Values were expressed as international units of activity in grams of tissue $\left(\mathrm{U} \mathrm{g}^{-1}\right)$.

\section{Hematological variables}

Hematological variables were determined for fresh blood taken from fish tail veins using heparinized syringes. Hematocrits (HT) were measured by a centrifugation method with micro capillary tubes (heparinized in vitro), and compared with a percentage table of micro hematocrits (GolDENFARB et al., 1971).

To measure hemoglobin values (HB), grams per each deciliter of blood $\left(\mathrm{g} \mathrm{dL}^{-1}\right)$ (COLliER, 1944). Corpuscular hemoglobin concentration index (CHCM) was calculated as $\mathrm{CHCM}=100\left(\mathrm{HB} \mathrm{HT}^{-1}\right)$, with $\mathrm{HT}$ expressed in $\mathrm{g} \mathrm{dL}^{-1}$.

\section{Statistical analysis}

Data were tested for normality using Shapiro-Wilk tests, and were analyzed by polynomial regression and linear response plateau (LRP) analysis with the minimums squared method, according to the model $\mathrm{Y}$ $=\mathrm{L}+\mathrm{U} *(\mathrm{RX})$, where $\mathrm{Y}=$ value of the variable analyzed, $\mathrm{X}=$ percentage of MPM inclusion, $\mathrm{L}=$ plateau response of the studied variable; $U$ = slope of the line, and $\mathrm{R}=$ inclusion of MPM estimated by the intercept point (RoBBINS et al., 1979). The Dunnett test was performed to compare the control treatment with the other treatments. Models with the best fit for each variable were chosen. All procedures were conducted the SAS $^{\circledR}$ University Edition statistical package.

\section{RESULTS}

In both trials, there was no mortality of experimental fish. During the trials, average water temperatures were $26.00 \pm 0.50^{\circ} \mathrm{C}$, $\mathrm{pH}$ was $6.80 \pm 0.40$, and dissolved oxygen was $4.80 \pm 0.30 \mathrm{mg} \mathrm{L}^{-1}$.

\section{Digestibility Trial}

Apparent digestibility of crude energy and crude protein was low, $44.55 \%$ and $50.18 \%$, respectively. The average digestibility of amino acids was $56.81 \%$, with a value of $56.28 \%$ for the average digestibility of essential amino acids (Table 4). 
Table 4. Apparent digestibility and availability coefficients of mango pulp meal.

\begin{tabular}{cc}
\hline Nutrients & ADC $^{1}(\%)$ \\
\hline Dry matter & 39.26 \\
Crude protein & 50.18 \\
Gross energy & 44.55 \\
Essential amino acids & \\
Arginine & 39.55 \\
Histidine & 60.57 \\
Isoleucine & 57.91 \\
Leucine & 59.74 \\
Lysine & 59.00 \\
Methionine & 64.17 \\
Methionine + Cysteine & 53.09 \\
Phenylalanine & 60.89 \\
Threonine & 50.21 \\
Tryptophan & 58.10 \\
Valine & 55.87 \\
Alanine & \\
Proline & 57.55 \\
Cysteine & 55.72 \\
Serine & 42.43 \\
Tyrosine & 54.00 \\
Glycine & 64.05 \\
Aspartic acid & 44.36 \\
Glutamic acid & 70.91 \\
\hline
\end{tabular}

${ }^{1}$ Apparent digestibility coefficients of nutrients; ${ }^{2}$ Availability of essential amino acids; ${ }^{3}$ Availability nonessential amino acids.

\section{MPM inclusion trial}

All growth performance variables showed differences between treatments with the inclusion of MPM and the control treatment $(\mathrm{p}<0.05)$, except for FI and FCR (Table 5). None of the variables fit a model with a biological explanation to the experimental design of the study. 
Table 5 Growth performance and efficiency of tilapia fed diets with mango pulp inclusion.

\begin{tabular}{|c|c|c|c|c|c|c|c|c|c|c|}
\hline \multirow{3}{*}{ Variables } & \multicolumn{10}{|c|}{ Inclusion levels for mango pulp meal $\left(\mathrm{g} \mathrm{kg}^{-1}\right)$} \\
\hline & \multirow{2}{*}{$\begin{array}{c}0 \\
\text { (Control) } \\
\text { Mean }\end{array}$} & \multicolumn{2}{|c|}{40} & \multicolumn{2}{|c|}{80} & \multicolumn{2}{|c|}{120} & \multicolumn{2}{|c|}{160} & \multirow[t]{2}{*}{ SEM } \\
\hline & & Mean & $\begin{array}{c}p \\
\text { value }\end{array}$ & Mean & $\begin{array}{c}p \\
\text { value }\end{array}$ & Mean & $\begin{array}{c}p \\
\text { value }\end{array}$ & Mean & $\begin{array}{c}p \\
\text { value }\end{array}$ & \\
\hline $\mathrm{FW}(\mathrm{g})^{1}$ & 89.78 & $78.53 *$ & 0.01 & $80.09 *$ & 0.02 & $80.35^{*}$ & 0.03 & $80.50^{*}$ & 0.03 & 1.26 \\
\hline $\mathrm{FB}(\mathrm{g})^{2}$ & 1347 & $1178 *$ & 0.01 & $1201 *$ & 0.02 & $1205^{*}$ & 0.03 & $1207 *$ & 0.03 & 18.94 \\
\hline WG $(g)^{3}$ & 63.40 & $52.00 *$ & 0.01 & $53.49 *$ & 0.02 & $53.38 *$ & 0.02 & $53.68^{*}$ & 0.02 & 1.29 \\
\hline $\mathrm{BG}(\mathrm{g})^{4}$ & 951 & $780^{*}$ & 0.01 & $802 *$ & 0.02 & $800 *$ & 0.02 & $805^{*}$ & 0.02 & 19.39 \\
\hline $\mathrm{TGC}^{5}$ & 1.33 & $1.15^{*}$ & 0.01 & $1.18^{*}$ & 0.02 & $1.17^{*}$ & 0.02 & $1.18^{*}$ & 0.02 & 0.02 \\
\hline FI $(g)^{6}$ & 1160 & 1169 & 1.00 & 1214 & 0.76 & 1212 & 0.77 & 1223 & 0.65 & 17.11 \\
\hline $\mathrm{FCR}^{7}$ & 1.24 & 1.50 & 0.12 & 1.52 & 0.09 & 1.53 & 0.07 & 1.52 & 0.08 & 0.04 \\
\hline
\end{tabular}

*Values differ from the control treatment by the Dunnett test $(p>0.05) .{ }^{1} \mathrm{FW}=$ final weight; ${ }^{2} \mathrm{FB}=$ final biomass; ${ }^{3} \mathrm{WG}=$ weight gain; ${ }^{4} \mathrm{BG}=$ biomass gain; ${ }^{5} \mathrm{TGC}=$ thermal growth coefficient; ${ }^{6} \mathrm{FI}=$ Feed intake; ${ }^{7} \mathrm{FCR}$ $=$ Feed conversion ratio.

No differences were observed between hematological variables. Among the plasma variables, difference was observed in glucose, AST, ALT and TPAA, as well in hepatic glycogen $(p<0.05)$ (Table 6). Only plasma glucose adjusted to a model with biological explanation (Figure 1). 
Table 6. Metabolites, plasma enzymatic activity, and hematology of the Nile tilapia fed diets with mango pulp inclusion.

\begin{tabular}{|c|c|c|c|c|c|c|c|c|c|c|}
\hline \multirow{3}{*}{ Variable } & \multicolumn{10}{|c|}{ Inclusion levels ( $\left.\mathrm{g} \mathrm{kg}^{-1}\right)$} \\
\hline & \multirow{2}{*}{$\begin{array}{c}0 \text { (Control) } \\
\text { mean }\end{array}$} & \multicolumn{2}{|c|}{40} & \multicolumn{2}{|c|}{80} & \multicolumn{2}{|c|}{120} & \multicolumn{2}{|c|}{160} & \multirow{2}{*}{ SEM } \\
\hline & & mean & $p$ value & mean & $p$ value & mean & $p$ value & mean & $p$ value & \\
\hline \multicolumn{11}{|c|}{ Plasma metabolites } \\
\hline Albumin $\left(\mathrm{g} \mathrm{dL}^{-1}\right)$ & 0.80 & 0.62 & 0.31 & 0.63 & 0.35 & 0.69 & 0.69 & 0.57 & 0.13 & 0.03 \\
\hline Total proteins $\left(\mathrm{g} \mathrm{dL}^{-1}\right)$ & 3.18 & 2.94 & 0.74 & 3.16 & 1.00 & 3.03 & 0.93 & 2.84 & 0.47 & 0.07 \\
\hline Cholesterol (mg dL $\left.{ }^{-1}\right)$ & 80.81 & 88.97 & 0.82 & 73.79 & 0.88 & 94.86 & 0.43 & 88.90 & 0.82 & 3.21 \\
\hline Glucose (mg dL-1) & 70.07 & 69.18 & 1.00 & 65.27 & 0.99 & 101.95 & 0.08 & $138.99 *$ & 0.01 & 7.41 \\
\hline \multicolumn{11}{|c|}{ Plasma enzymatic activity } \\
\hline $\operatorname{ALT}\left(\mathrm{U} \mathrm{L}^{-1}\right)$ & 7.86 & 9.38 & 0.86 & $14.66^{*}$ & 0.01 & $14.61 *$ & 0.01 & 11.65 & 0.22 & 0.84 \\
\hline $\operatorname{AST}\left(\mathrm{U} \mathrm{L}^{-1}\right)$ & 53.12 & 139.91 & 0.15 & $188.63 *$ & 0.02 & $254.51 *$ & 0.01 & $204.08^{*}$ & 0.01 & 19.40 \\
\hline TPAA $\left(\mu \mathrm{mol} \mu \mathrm{L}^{-1}\right)$ & 37.85 & 37.14 & 1.00 & 35.96 & 0.87 & 38.59 & 0.99 & $45.15^{*}$ & 0.04 & 1.03 \\
\hline \multicolumn{11}{|c|}{ Hematology } \\
\hline HT (\%) & 45.05 & 38.25 & 0.63 & 43.75 & 1.00 & 45.00 & 1.00 & 46.25 & 1.00 & 1.19 \\
\hline $\mathrm{HB}\left(\mathrm{g} \mathrm{dL}^{-1}\right)$ & 3.54 & 3.44 & 0.99 & 3.18 & 0.50 & 3.17 & 0.49 & 3.33 & 0.85 & 0.08 \\
\hline $\mathrm{CHCM}\left(\mathrm{g} \mathrm{dL}^{-1}\right)$ & 7.85 & 8.61 & 0.73 & 6.99 & 0.64 & 7.09 & 0.72 & 7.37 & 0.92 & 0.26 \\
\hline \multicolumn{11}{|c|}{ Hepatic tissue } \\
\hline Total proteins $\left(\mu \mathrm{mol} \mathrm{mg}^{-1}\right)$ & 2.63 & 2.39 & 0.64 & 2.47 & 0.88 & 2.98 & 0.31 & 2.78 & 0.88 & 0.07 \\
\hline Glycogen $\left.(\mu \mathrm{mol} \mathrm{mg})^{-1}\right)^{5}$ & 53.13 & $127.98^{*}$ & 0.01 & $120.32 *$ & 0.01 & $114.24 *$ & 0.02 & $121.60 *$ & 0.01 & 7.55 \\
\hline
\end{tabular}

**Values differ from the control treatment by the Dunnett test $(p>0.05)$.

${ }^{1} \mathrm{ALT}=$ alanine amino transferase $;{ }^{2} \mathrm{TPAA}=$ total plasmatic amino acids; ${ }^{3} \mathrm{HT}=$ hematocrit; ${ }^{4} \mathrm{HB}=$ hemoglobin; ${ }^{4} \mathrm{CHCM}=$ corpuscular hemoglobin concentration index;

${ }^{5}$ Glycogen expressed in micro moles of glycosil-glucose for each milligram of hepatic tissue. 


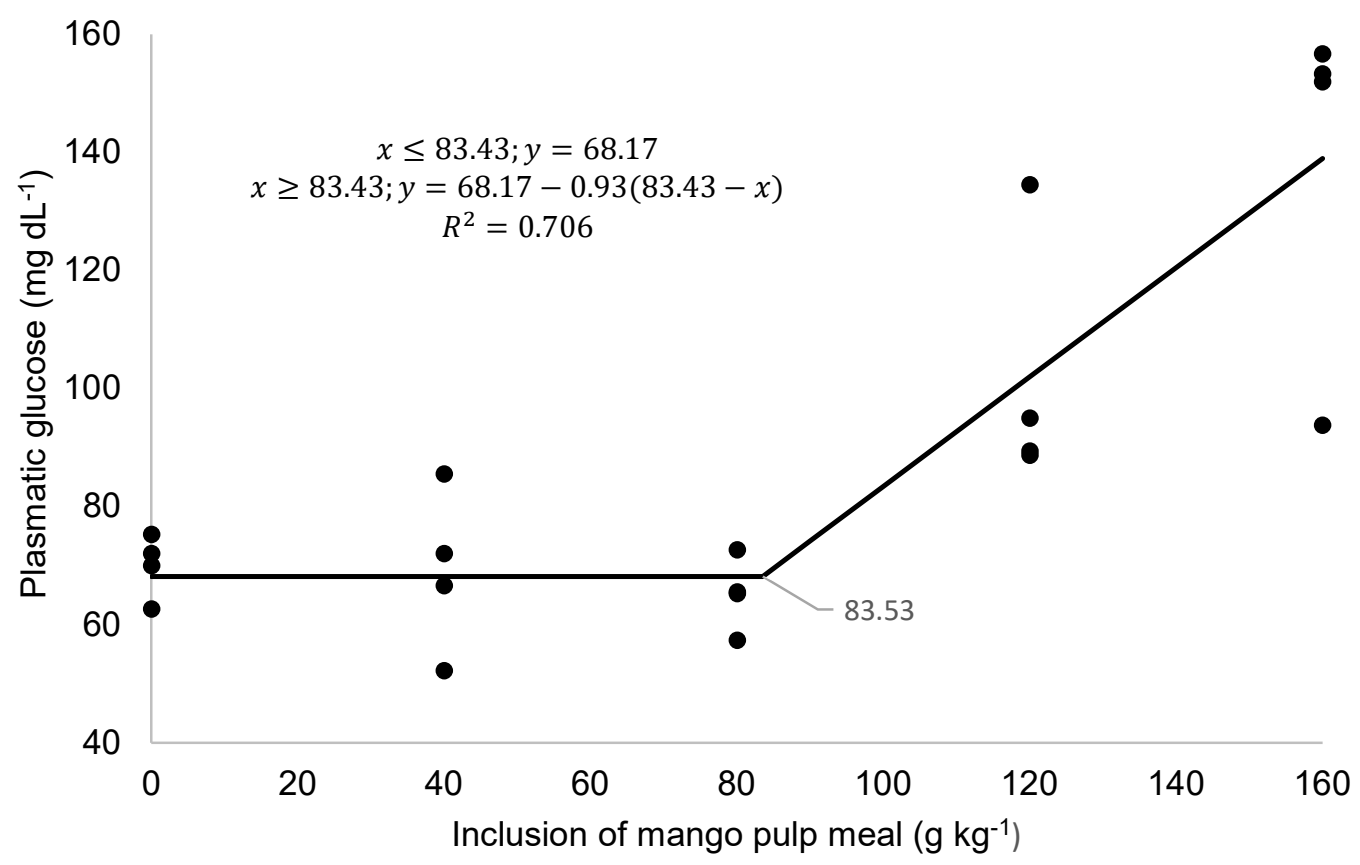

Figure 1. Linear Response Plateau of plasmatic glucose concentrations of Nile tilapia fed diets with different levels of mango pulp meal.

Among digestive enzymes, only amylase activity differed $(\mathrm{p}<0.05)$ between the control treatment and the treatments with the inclusion of MPM (Table 7). It was observed that the amylase activity was reduced until the inclusion of $118.20 \mathrm{~g}$ $\mathrm{kg}-1$ of MPF, from that point on, a plateau was observed (Figure 2). 
Table 7 Digestive enzymatic activity in Nile tilapia fed diets with mango pulp inclusion.

\begin{tabular}{|c|c|c|c|c|c|c|c|c|c|c|}
\hline \multirow{3}{*}{$\begin{array}{c}\text { Variable } \\
\mathrm{s} \\
\left(\mathrm{U} \mathrm{mg}^{-1}\right. \\
\text { protein })\end{array}$} & \multicolumn{10}{|c|}{ Inclusion levels $\left(\mathrm{g} \mathrm{kg}^{-1}\right)$} \\
\hline & $\begin{array}{c}0 \\
\text { (Control }\end{array}$ & 4 & & 8 & & 12 & & 16 & & \\
\hline & mean & mean & $\begin{array}{c}p \\
\text { valu } \\
\mathrm{e}\end{array}$ & mean & $\begin{array}{c}p \\
\text { valu } \\
\mathrm{e}\end{array}$ & mean & $\begin{array}{c}p \\
\text { valu } \\
\mathrm{e}\end{array}$ & mean & $\begin{array}{c}p \\
\text { valu } \\
\mathrm{e}\end{array}$ & \\
\hline Amylase & 77.95 & 58.12 & 0.10 & $\begin{array}{c}50.27 \\
*\end{array}$ & 0.01 & $27.82 *$ & 0.01 & $\begin{array}{c}33.49 \\
*\end{array}$ & 0.01 & 4.22 \\
\hline Lipase & 675.60 & $\begin{array}{c}776.6 \\
3\end{array}$ & 0.97 & $\begin{array}{c}849.0 \\
8\end{array}$ & 0.82 & $\begin{array}{c}1.067 .1 \\
5\end{array}$ & 0.21 & $\begin{array}{c}889.7 \\
3\end{array}$ & 0.69 & $\begin{array}{c}65.5 \\
7\end{array}$ \\
\hline $\begin{array}{c}\text { Non- } \\
\text { specific } \\
\text { protease }\end{array}$ & 2.22 & 2.02 & 0.98 & 2.60 & 0.82 & 1.77 & 0.74 & 2.36 & 0.99 & 0.15 \\
\hline
\end{tabular}

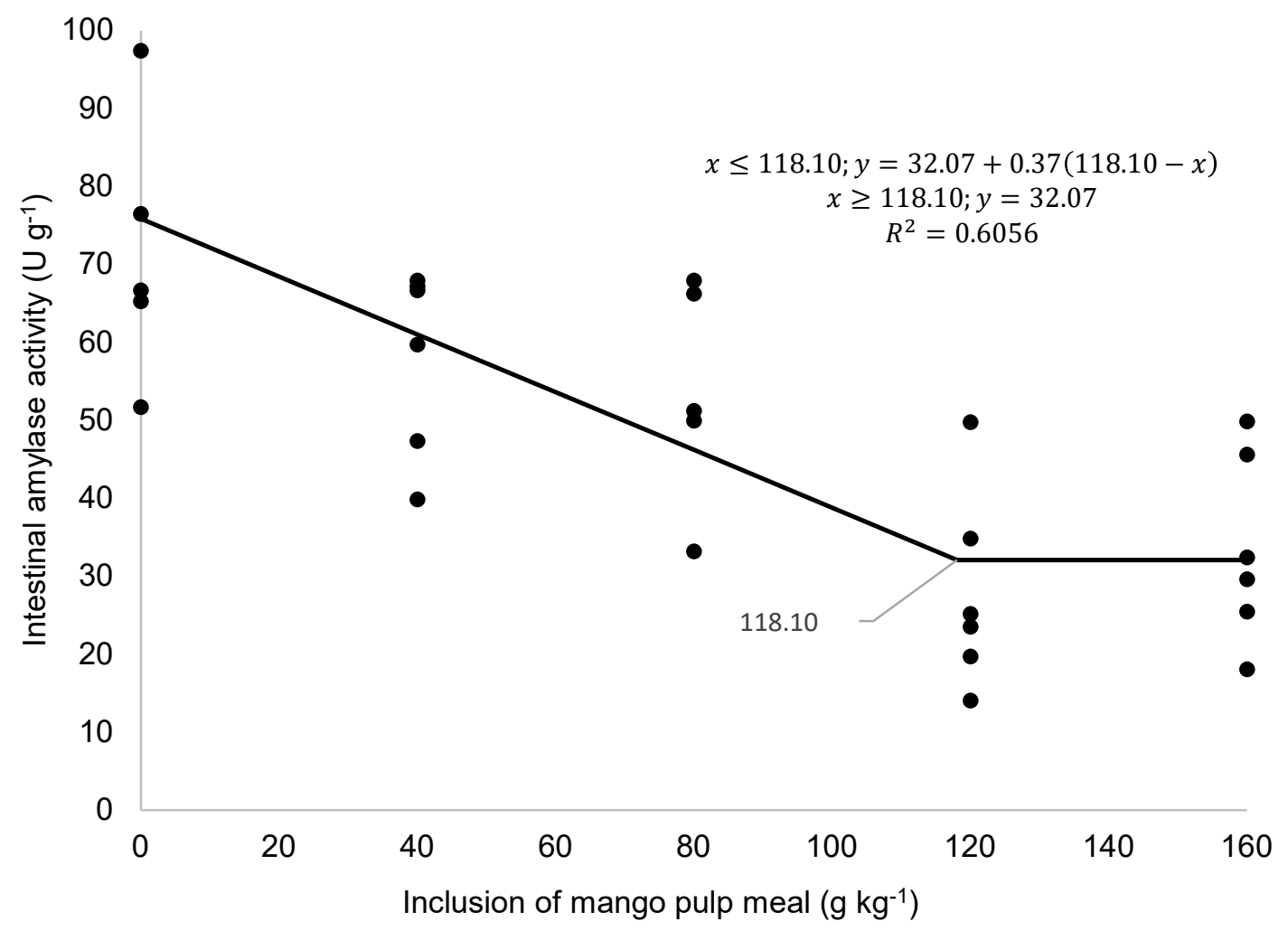


Figure 2. Linear Response Plateau regression of intestinal amylase activity of Nile tilapia fed diets with different levels of mango pulp meal.

\section{DISCUSSION}

The levels of dry matter (DM) and crude protein $(\mathrm{CP})$ of the mango pulp meal were similar to those describe for de Lima et al. (2011) for Nile tilapia and Vieira et al. (2008) for poultry, respectively, with $\mathrm{DM}=941.00 \mathrm{~g} \mathrm{~kg}^{-1}$ and $\mathrm{CP}=44.40 \mathrm{~g} \mathrm{~kg}^{-1}$ and $\mathrm{DM}=922.30$ $\mathrm{g} \mathrm{kg}^{-1}$ and $\mathrm{CP}=38.70 \mathrm{~g} \mathrm{~kg}^{-1}$, by studying the composition of industrial solid residues from the fruit pulp industry, containing fruit peels and seeds. Concentrations of crude fiber (CF) observed were different from the actual level of $\mathrm{CF}=149.90 \mathrm{~g} \mathrm{~kg}^{-1}$ and $\mathrm{GE}=$ $3.724 \mathrm{kcal} \mathrm{kg}^{-1}$ in the study de Lima et al. (2011), and $146.00 \mathrm{~g} \mathrm{~kg}^{-1}$ and $3.906 \mathrm{kcal}$ $\mathrm{kg}^{-1}$ in the study by Vieira et al. (2008). Digestibility coefficients for MS, PB, and EB of MPM in our study were lower than those described by de Lima et al. (2011), , who reported values of 78.00, 87.80 and $77.50 \%$ respectively. This was likely because de Lima et al. (2011) worked with residues lacking soluble fruit pulp extract. According to Lazzari et al. (2015), mango pulp contains carbohydrates in the forms of fructose, cornstarch, and pectins. These molecules store high amounts of energy in chemical bonds (VERGARA-VALENCIA et al., 2007). However, pectin is a non-starchy carbohydrate and has low digestibility because it is resistant to breakdown by enzymatic hydrolysis or heat treatment (OliveIRA et al., 2007).

Although Nile tilapia are omnivorous and capable of consuming pectins and other non-starchy carbohydrates normally included in their diet (KROGDAHL et al., 2005), such carbohydrates can adversely affect hydrolysis of proteins. This can occur even in fish species such as Nile tilapia (KROGDAHL et al., 2005), which have active $\beta$-galactosidase (type of pectin) in their anterior and middle intestines (TANIGUCHI AND TAKANO, 2004). Furthermore, Irvin et al. (2016), described negative effects of pectin on digestibility of energy and nutrients in barramundi fish (Lates calcarifer), and pectin could also affect the viscosity and transit velocity in intestines. These results are supported by those of Castillo and Gatlin (2015), who found that addition of exogenous carbohydrase to the diet of juvenile tilapia increased the digestibility of vegetable ingredients. Therefore, compared with pulp residues, we would expect that MPM has lower digestibility of nutrients and energy, and lower availability of amino acids, because of greater interference from soluble fibers that are indigestible, such as pectin.

Increasing concentrations of MPM lead to a significant performance changes ( $p$ $>0.05)$ in the juvenile tilapia tested during our study, results are not consistent with those of de Lima et al. (2011) and Melo et al. (2012). Although both of those studies used juvenile tilapia, they were conducted using agroindustrial residues resulting from mango pulp meal processing. These two studies did not detect any performance decrease with an inclusion of a maximum 150 or $300 \mathrm{~g}$ MPM per $\mathrm{kg}$ of diet, respectively. In contrast, Souza et al. (2013), who tested MPM that included peels, observed a reduction in performance of Nile tilapia with increasing MPM 
concentrations. Therefore, we advise against inclusion of MPM levels over $100 \mathrm{~g} \mathrm{~kg}^{-1}$ because of the harmful effects of phenols, such as tannins contained in peels, even though this possibility was not directly assessed in our study.

Melo et al. (2012) replaced corn bran in juvenile Nile tilapia diets with variable levels of mango pulp $(0,33,66$, or $100 \%$ ) and did not observe any effect of mango pulp on feed intake or FCR, as we did in our study. However, Souza et al. (2013), observed a negative effect on feed intake and FCR of a MPM including peels, at concentrations of over $200 \mathrm{~g}$ of MPM per kg of diet. This negative effect may have been due to phenolic contents of fruit peels that were incorporated in the MPM. Pinto et al. (2001) reported negative effects of tannins on the digestion process of juvenile tilapia, for concentrations equal to or higher than 6 $\mathrm{g} \mathrm{kg}^{-1}$. These concentrations were much higher than the ones in our study (total phenols of $0.62 \mathrm{gAT} \mathrm{kg}^{-1}$ ).

According to Rosset et al. (2016), ingestion of large quantities of fructose leads to an increase in the production of metabolic intermediates involved in fructolysis, the process of converting fructose to glucose, lactate, glycerol, and fatty acids, or for use in oxidative metabolism in mitochondria. A similar effect was found in our study, and by Bezerra et al. (2014), who tested levels of $200,300,400$, and $500 \mathrm{~g} \mathrm{~kg}^{-1}$ of MPM in the diet of the tambaqui fish (Colossoma macropomum). That study reported changes in glycogen hepatic reserves corresponding to the level of MPM inclusion in diets. However, results of de Lima et al. (2011), who incorporated levels of $0,50,100$, and 150 $\mathrm{g} \mathrm{kg}^{-1}$ of MPM in the tilapia diet, differed from results in our study in that they did not observe an effect of MPM on glycogen reserves. These contrasting results might have occurred because the type of mango residue used by de Lima et al. (2011) had lower amounts of fructose, which was removed by a fruit processing step.

Amylase, a pancreatic enzyme secreted in the intestine, is responsible for hydrolysis of polysaccharides. Its activity is related to the utilization of different levels of starchy carbohydrates in food, and varies according to feeding routines of species (STECH et al., 2009).

The activity of plasmatic ALT increased with the inclusion MPM. this enzyme is present in several tissues of the body, especially hepatocytes. Elevation in plasma ALT is associated with increased permeability of cytoplasmic membranes, oxidative stress, and metabolic imbalance (JONSSON et al., 2002; KOBAYASHI et al., 2009).

According to Rosset et al. (2016), fructose absorption has no regulation system like that of glucose. Hence, ingestion of large quantities of fructose can lead to a cytoplasmic increase in fructose concentration. Fructose would then be phosphorylated, leading to depletion of hepatic adenosine triphosphate (ATP) reserves, and an increase in the turnover of proteins, especially those involved in deamination of amino acids for energy purposes. Higher fructose levels in diets would reduce transamination of amino acids for energy production, leading to what Boscolo et al. (2011) described as a protein-saving effect of carbohydrates. In a subsequent study, higher concentrations of fructose increased the activity of ALT, leading to a prooxidative effect when $100 \mathrm{~g} \mathrm{~kg}^{-1}$ lyophilized mango pulp meal was 
included in the diet of rats (TOLEDO et al., 2013). This may have been because the lyophilized mango pulp meal led to a mobilization of amino acids in order to keep appropriate glucose levels in blood and to preserve hepatic glycogen reserves through gluconeogenesis. This side effect was also noted by (BEZERRA et al., 2014), who tested mango pulp levels (ranging from 200 to $500 \mathrm{~g} \mathrm{~kg}^{-1}$ ) in the diet of tambaquis. High levels of fructose in diets containing MPM can cause oxidative damage to hematocrits and increase plasmatic activity of enzymes similar to ALT. However, MPM levels did not influence hematologic variables. Akrami et al. (2013), researched the prebiotic effect of polymeric carbohydrates of fructose (fruitoligosaccharides) in a sturgeon species (Acipenser stellatus), and only observed an increase in average levels of white blood cells. They did not report any significant differences in the hematimetric index.

The effect of including MPM on digestive enzyme activity was similar to that observed when replacing corn with mesquite bran in diets for Nile tilapia. Some enzymes have their production related to the amount of the substrate that catalyzes, thus, the lower proportion of starch induces less amylase production and directs the body's efforts to produce other carbohydrases (DE SouzA et al., 2018).

In our study, we prepared isoproteic and isoenergetic diets in order to control for carbohydrate compositions of MPM. Consequently, there none of the risk factors described above could have affected the hematologic variables we analyzed. We found that the inclusion of MPM in diets for Nile tilapia reduced the parameters of fish growth, on the other hand, the hematological parameters do not indicate a significant impact on health in the evaluated period. Furthermore, our data concerning metabolism indicated that inclusion of $54.14 \mathrm{~g} \mathrm{~kg}^{-1}$ or greater concentrations resulted in metabolism changes in proteins. Therefore, future research to evaluate metabolic and cellular damage by long-term ingestion of MPM could be valuable.

\section{Acknowledgment}

To the "Fundação de Amparo à Pesquisa do Estado da Bahia - FAPESB", through the grant term RED0027 / 2014.

\section{REFERENCES}

AKRAMI, R.; IRI, Y.;

KHOSHBAVAR ROSTAMI, H.; RAZEGHI MANSOUR, M. Effect of dietary supplementation of fructooligosaccharide (FOS) on growth performance, survival, lactobacillus bacterial population and hematoimmunological parameters of stellate sturgeon (Acipenser stellatus) juvenile.

Fish \& Shellfish Immunology, v. 35, n. 4, p. 1235-1239, 2013.

AOAC. Official methods of analysis of AOAC International. Gaithersburg, Md.: AOAC International, 2005. ISBN 1080-0344 0935584757

9780935584752 .

BEZERRA NETO, E.; BARRETO, L.P. Análises químicas e bioquímicas em plantas. Editora Universitária da UFRPE, 2011. 261

BEZERRA, S.K.; SOUZA, R.C.; MELO, J.F.B.; CAMPECHE, D.F.B. 
Crescimento de tambaqui alimentado com diferentes niveis de farinha de manga e proteína na ração. Archivos de Zootecnia, v. 63, n. 244, p. 587-598, 2014.

BIDINOTTO, P.M.; MORAES, G.; SOUZA, R.H.S. Hepatic glycogen and glucose in gigth tropical freshwater teleost fish: A procedure for field determinations of micro samples.

Boletim Técnico CEPTA, p. 53-60, 1997.

BOSCOLO, W.R.; SIGNOR, A.; FREITAS, J.M.A.D.; BITTENCOURT, F.; FEIDEN, A. Nutrição de peixes nativos. Revista Brasileira de Zootecnia, v. 40, p. 145-154, 2011.

CASTILLO, S.; GATLIN, D.M.

Dietary supplementation of exogenous carbohydrase enzymes in fish nutrition: A review. Aquaculture, v. 435, p. 286292, 2015.

COLLIER, H.B. Standardization of Blood Haemoglobin Determinations. Canadian Medical Association journal, v. 50, n. 6, p. 550-2, 1944.

DE CAMPOS, R.F.F.; DE LIMA, C. Sustentabilidade através de remanejo de resíduos com pratica de gestão ambiental implantado no supermercado cereal. Ignis: Periódico Científico de Arquitetura e Urbanismo, Engenharias e Tecnologia da Informação, v. 3, n. 1, p. 25-44, 2014.

DE LIMA, M.R.; LUDKE, M.D.C.M.M.; PORTO NETO, F.D.F.; PINTO, B.W.C.; TORRES, T.R.; DE SOUZA, E.J.O. Farelo de resíduo de manga para tilápia do Nilo. Acta
Scientiarum. Animal Sciences, v. 33, n. 1, p. 65-71, 2011.

DE SOUZA, A.M.; SILVA, A.T.; FELIX E SILVA, A.; CAMPECHE, D.F.B.; MELO, J.F.B.; VIDAL, L.V.O. Mesquite bean ( Prosopis juliflora ) meal in diets of Nile tilapia ( Oreochromis niloticus): Nutritional value, growth, physiological responses and health. Aquaculture Research, n. May, p. 1-14, 2018.

DURIGAN, M.F.B.; MATTIUZ, B.-H.; DURIGAN, J.F. Injúrias mecânicas na qualidade pós-colheita de lima ácida 'Tahiti' armazenada sob condição ambiente. Revista Brasileira de Fruticultura, v. 27, n. 3, p. 369-372, 2005.

FELIX E SILVA, A.; COPATTI, C.E.; DE OLIVEIRA, E.P.; BONFÁ, H.C.; MELO, F.V.S.T.D.; CAMARGO, A.C.D.S.; MELO, J.F.B. Effects of whole banana meal inclusion as replacement for corn meal on digestibility, growth performance, haematological and biochemical variables in practical diets for tambaqui juveniles (Colossoma macropomum). Aquaculture Reports, v. 17, n. September 2019, p. 100307-100307, 2020.

FURUKAWA, A.; TSUKAHARA, H. On the acid digestion method for the determination of chromic oxide as an index substance in the study of digestibility of fish feed. Nippon

Suisan Gakkaishi, v. 32, n. 6, p. 502506, 1966.

FURUYA, W.M.; PEZZATO, L.E.; BARROS, M.M.; BOSCOLO, W.R.; 
CYRINO, J.E.P.; FURUYA, V.R.B.; FEIDEN, A. Tabelas Brasileiras para a nutrição de tilápias. 1. Toledo: GFM Gráfica \& Editora, 2010. 100-100

GLENCROSS, B.D.; BOOTH, M.; ALLAN, G.L. A feed is only as good as its ingredients - a review of ingredient evaluation strategies for aquaculture feeds. Aquaculture Nutrition, v. 13, n. 1, p. 17-34, 2007.

GOLDENFARB, P.B.; BOWYER, F.P.; HALL, E.; BROSIOUS, E.

Reproducibility in the hematology laboratory: the microhematocrit determination. American journal of clinical pathology, v. 56, n. 1, p. 35-9, 1971.

IRVIN, S.; BLYTH, D.; BOURNE, N.; GLENCROSS, B. A study of the discrete and interactive effects of different polysaccharides on the digestibility of diets fed to barramundi (Lates calcarifer). Aquaculture Nutrition, v. 22, n. 5, p. 1047-1054, 2016.

JONSSON, C.M.; FERRACINI, V.L.; PARAÍBA, L.C.; RANGEL, M.; AGUIAR, S.R. Alterações bioquímicas e acúmulo em pacus (Metynnis argenteus) expostos ao paclobutrazol. Scientia Agricola, v. 59, p. 441-446, 2002.

KOBAYASHI, A.; SUZUKI, Y.; KUNO, H.; SUGAI, S.; SAKAKIBARA, H.; SHIMOI, K. Effects of fenofibrate on plasma and hepatic transaminase activities and hepatic transaminase gene expression in rats. The Journal of Toxicological Sciences, v. 34, n. 4, p. 377-387, 2009.
KROGDAHL, A.; HEMRE, G.I.; MOMMSEN, T.P. Carbohydrates in fish nutrition: digestion and absorption in postlarval stages. Aquaculture Nutrition, v. 11, n. 2, p. 103-122, 2005.

LAZZARI, R.; UCZAY, J.; RODRIGUES, R.B.; PIANESSO, D.; ADORIAN, T.J.; MOMBACH, P.I. Utilização de resíduos de frutas em dietas para piava. Boletim do Instituto de Pesca, v. 41, n. 2, p. 227-237, 2015.

MARTINS, C.R.; FARIAS, R.D.M. Revista da Faculdade de Zootecnia, Veterinária e Agronomía. Pontifícia Universidade Católica do Rio Grande do Sul, 1994.

MELO, J.F.B.; SEABRA, A.G.L.; SOUZA, S.A.; SOUZA, R.C.; FIGUEIREDO, R.A.C.R. Substituição do farelo de milho pela farinha de manga no desempenho da tilápia-donilo. Arquivo Brasileiro de Medicina Veterinária e Zootecnia, v. 64, n. 1, p. 177-182, 2012.

NRC. Nutrient Requirements of fish and shrimp. Washington: The National Academy Press, 2011. 376-376

OLIVEIRA, G.R.D.; LOGATO, P.V.R.; FREITAS, R.T.F.D.; RODRIGUES, P.B.; FIALHO, E.T.; DIODATTI, F.C. Digestibilidade de nutrientes em ração com complexo enzimático para tilápiado-nilo. Revista Brasileira de Zootecnia, v. 36, n. 6, p. 1945-1952, 2007.

PINTO, L.G.Q.; PEZZATO, L.E.; MIRANDA, E.C.D.; BARROS, M.M. 
Desempenho do piauçu (Leporinus macrocephalus) arraçoado com dietas contendo diferentes teores de tanino.

Revista Brasileira de Zootecnia, v. 30, n. 4, p. 1164-1171, 2001.

ROBBINS, K.R.; NORTON, H.W.; BAKER, D.H. Estimation of nutrient requirements from growth data. The Journal of nutrition, v. 109, n. 10, p. 1710-4, 1979.

ROSSET, R.; SUROWSKA, A.; TAPPY, L. Pathogenesis of Cardiovascular and Metabolic Diseases: Are Fructose-Containing Sugars More Involved Than Other Dietary Calories? Current Hypertension Reports, v. 18, n. 6, p. 44-44, 2016.

SILVA, C.B.; VALENTE, L.M.P.; MATOS, E.; BRANDÃO, M.; NETO, B. Life cycle assessment of aquafeed ingredients. International Journal of Life Cycle Assessment, v. 23, n. 5, p. 995-1017, 2018.

SOUZA, R.C.; MELO, J.F.B.; NOGUEIRA FILHO, R.M.; CAMPECHE, D.F.B.; FIGUEIREDO, R.A.C.R. Influencia da farinha de manga no crescimento e composição corporal da tilápia do Nilo. Archivos de Zootecnia, v. 62, n. 238, p. 217-225, 2013.

STECH, M.R.; CARNEIRO, D.J.; JÚNIOR, J.M.P. Fatores que afetam a produção de enzimas digestivas em peixes e o uso de enzimas exógenas como ferramentas em nutrição de peixes. Ensaios e Ciência Ciências Biológicas, Agrárias e da Saúde, v. 13, n. 2, p. 79-93, 2009.
TANIGUCHI, A.Y.; TAKANO, K. Purification and properties of betagalactosidase from Tilapia intestine: Digestive enzyme of Tilapia-X. Fisheries Science, v. 70, n. 4, p. 688694, 2004.

TOLEDO, R.C.L.; BRITO, L.F.D.; RIBEIRO, S.M.R.; PELUZIO, M.D.C.G.; SIQUEIRA, C.L.M.D.; QUEIROZ, J.H.D. Efeito da ingestão da polpa de manga (Mangifera indica 1 .) sobre os parâmetros bioquímicos séricos e integridade hepática em ratos.

Bioscience Journal, v. 29, n. 2, 2013.

VERGARA-VALENCIA, N.; GRANADOS-PÉREZ, E.; AGAMAACEVEDO, E.; TOVAR, J.; RUALES, J.; BELLO-PÉREZ, L.A. Fibre concentrate from mango fruit: Characterization, associated antioxidant capacity and application as a bakery product ingredient. LWT - Food Science and Technology, v. 40, n. 4, p. 722-729, 2007.

VIEIRA, P.A.F.; QUEIROZ, J.H.D.; ALBINO, L.F.T.; MORAES, G.H.K.D.; BARBOSA, A.D.A.; MÜLLER, E.S.; VIANA, M.T.D.S. Efeitos da inclusão de farelo do resíduo de manga no desempenho de frangos de corte de $1 \mathrm{a}$ 42 dias. Revista Brasileira de Zootecnia, v. 37, n. 12, p. 2173-2178, 2008. 